\title{
Bacterial Incorporation of Organic Substances Released by Natural Phytoplankton Populations*
}

\author{
Karin Wolter
}

Institut für Meereskunde an der Universität Kiel, Düsternbrooker Weg 20, D-2300 Kiel, Federal Republic of Germany

\begin{abstract}
A modified differential filtration was used to measure extracellular release of primary products by natural phytoplankton populations and subsequent incorporation of these products by bacteria. Water samples were incubated with ${ }^{14} \mathrm{C}$ labelled bicarbonate for $6 \mathrm{~h}$ and $24 \mathrm{~h}$, respectively. A time course experiment showed that $6 \mathrm{~h}$ are sufficient for attaining an approximate isotopic equilibrium between the fractions of inorganic carbon and released organic carbon. Results reveal a strong relationship between primary production and release of organic substances. The highest concentrations of exudates $\left(239 \mu \mathrm{g} \mathrm{Cl}^{-1}\right)$ released by phytoplankton amounts to $27.6 \%$ of the primary production. Percentage of released substances depends on the composition of the algal populations. Skeletonema costatum released between $5.1 \%$ and $12.5 \%$ of the primary products; nanoflagellates, up to $40 \%$; Prorocentrum micans, slightly over $20 \%$; Chaetoceros sp., about $25 \%$. Up to $90 \%$ of available exudates were utilized by bacteria. Bacterial incorporation of exudates fluctuated during the year. The highest percentage of exudates was incorporated in the presence of dinoflagellates and nanoflagellates. Bacterial utilization of exudates is compared with that of glucose.
\end{abstract}

\section{INTRODUCTION}

Release of organic substances by phytoplankton and the physiological and ecological relevance of this mechanism have attracted special interest in recent years. Investigators used phytoplankton cultures (e. g. Hellebust, 1965; Nalewajko, 1966), as well as phytoplankton populations in fresh-water lakes (e.g. Nalewajko et al., 1976, Storch and Saunders, 1978), and in marine environments (e.g. Williams and Yentsch, 1976, Smith et al., 1977).

For better understanding of carbon fluxes in pelagic ecosystems it is necessary to investigate the release of organic substances by natural phytoplankton populations and the subsequent bacterial assimilation of such substrate. For this kind of experiment it has to be assumed that phytoplankton actually releases organic substances and that findings about released material are not due to sample handling. Values of exudate release by phytoplankton obtained from the literature range from 0 to over $50 \%$ of primary production. In his

\footnotetext{
- Publication No. 380 of the Joint Research Programme at Kiel University 'Interaction Sea-Sea Bottom' (Sonderforschungsbereich 95 der Deutschen Forschungsgemeinschaft)
}

review Sharp (1977) doubts that phytoplankton releases a significant fraction of assimilated carbon as DOC. He argues that observed exudation is probably an artefact.

Preliminary experiments using a chamber system and radioautograms have shown that release of exudates actually occurs and that bacteria incorporate these substances (Wolter, 1980). To minimize methodological interference during investigations, a careful filtration procedure was used. Correction factors were introduced to overcome difficulties of separating the autotrophic and heterotrophic population using differential filtration. Measuring bacterial utilization of naturally released exudates by adding labelled bicarbonate to the water sample, has the advantage that there is no need for addition of a special substrate, like glucose, to the water sample which might require adaptation by bacteria or cause the selection of special bacteria strains.

Bacteria are able to utilize organic substances released by phytoplankton. Larsson and Hagström (1979) demonstrated direct transfer of exudates from phytoplankton to bacteria. Bacterial incorporation of exudates was up to $25 \%$ of the primary production in a coastal ecosystem. Derenbach and Williams (1974) 
found that bacteria utilize phytoplankton exudates rapidly. Storch and Saunders (1978) and Larsson and Hagström (1979) report extracellular release following an annual pattern. According to Lee and Nalewajko (1978) maximum exudation occurred when mainly phytoflagellates were present in the water sample. In this paper, release of exudates and their bacterial utili- zation is described and related to the yearly cycle and pattern of phytoplankton species distribution. Bacterial utilization was measured only as incorporation of exudates (without respiration). An experiment was conducted to establish approximate isotopic equilibrium conditions. No differentiation was made between dissolved and colloidal substances in the exudate pool.

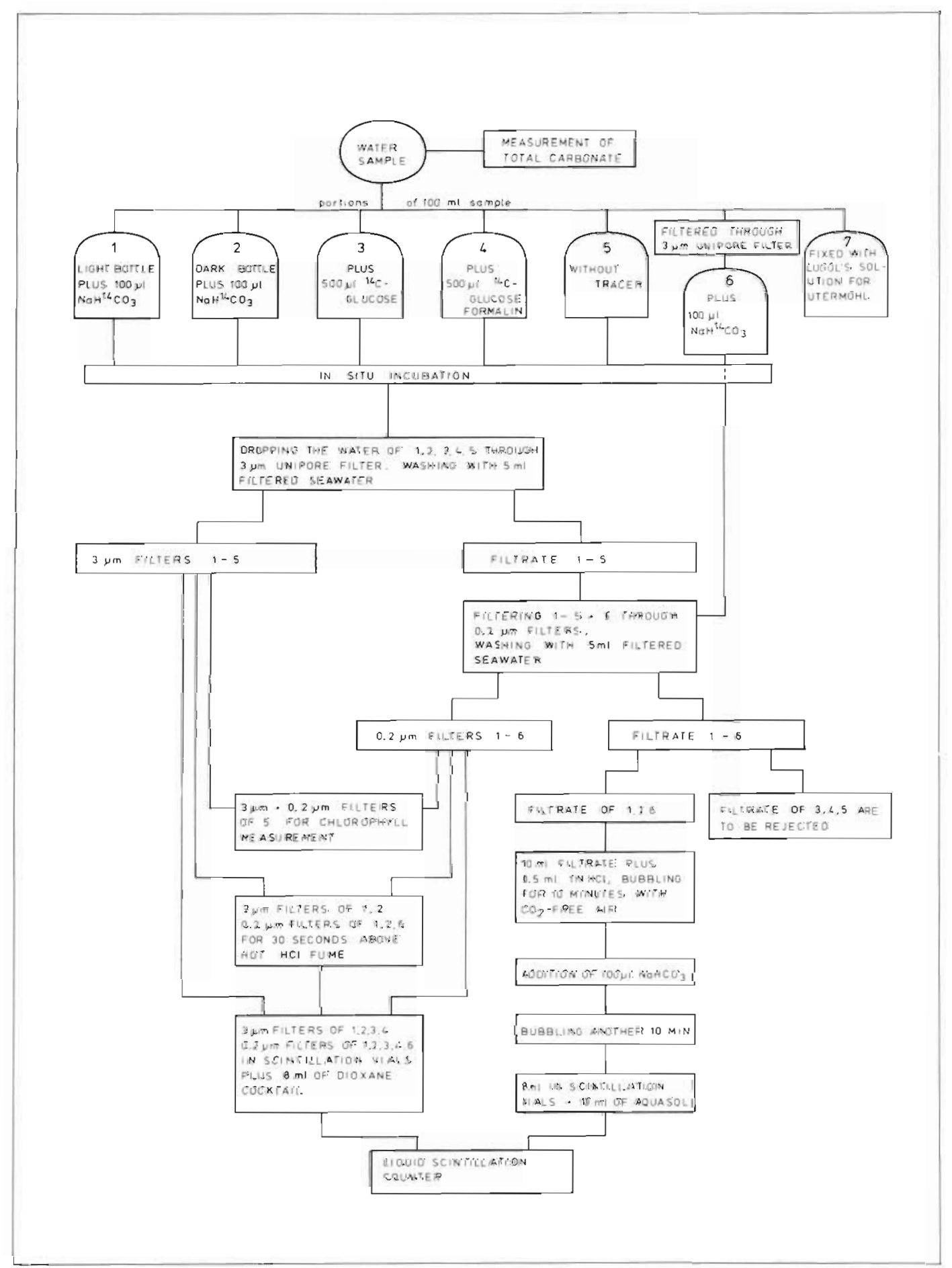

Fig. 1 Filtration procedure 


\section{MATERIAL AND METHODS}

Investigations were carried out at a station in the inner Kiel Fjord (Federal Republic of Germany). Every second week, 2-l samples were collected from $1 \mathrm{~m}$ depth. Water temperature and salinity were recorded with a TS-recorder (Electronic Switchgear Ltd, Type $\mathrm{MC}$ ). Two $100 \mathrm{ml}$ subsamples were filled into glassstoppered flasks and $10 \mu \mathrm{Ci} \mathrm{NaH}{ }^{14} \mathrm{CO}_{3}$ added (specific activity 40-60 $\left.\mathrm{mCi} \mathrm{mmol}{ }^{-1}\right)$. The samples were incubated in situ for 6 (9 a.m. to 3 p.m.) and 24 h (9 a.m. to 9 a.m.), respectively (Vial 1, Fig. 1). Following incubation, $1 \mathrm{ml}$ of water was removed and placed in a scintillation vial containing a drop of $1 \mathrm{~N} \mathrm{NaOH}$-solution. After adding $10 \mathrm{ml}$ Aquasol, total radioactivity was counted. Aliquots $(50 \mathrm{ml})$ were filtered immediately through $3 \mu \mathrm{m}$ polycarbonate filters (Biorad Laboratories, Unipore) without applying vacuum. The filters were rinsed with $5 \mathrm{ml}$ of seawater. Filtrates were collected and refiltered through $0.2 \mu \mathrm{m}$ polycarbonate filters under a vacuum not exceeding $100 \mathrm{~mm} \mathrm{Hg}(0.2$ $\mathrm{kpcm}^{-2}$ ). The filters were placed in the fume of hot concentrated HCL for $30 \mathrm{~s}$ in order to remove inorganic ${ }^{14} \mathrm{C}$. Thereafter the filters were placed in scintillation vials and 6 to $8 \mathrm{ml}$ of dioxane cocktail (120 g naphthaline, $5.5 \mathrm{~g}$ permablend and $1000 \mathrm{ml}$ aqua dest.) were added. Radioactivity was measured in a Berthold Betaszint BF 500 liquid scintillation counter. The filtrate $(10 \mathrm{ml})$ was acidified with $0.5 \mathrm{ml} 1 \mathrm{~N} \mathrm{HCL}$, and air was bubbled through the sample for $10 \mathrm{~min}$ to remove the inorganic ${ }^{14} \mathrm{C}$. Subsequently, $100 \mu \mathrm{l}$ of a saturated $\mathrm{NaHCO}_{3}$-solution was added and bubbling continued for a further $10 \mathrm{~min} ; 8 \mathrm{ml}$ were then placed in a scintillation vial, $10 \mathrm{ml}$ of Aquasol added, and the radioactivity determined. Quench correction factors were calculated using ${ }^{14} \mathrm{C}$-toluene as an internal standard for every type of sample, while the external channel ratio was run routinely to check if the samples were comparable. To correct for adsorption of ${ }^{14} \mathrm{CO}_{3}$ on the filter, and dark uptake of ${ }^{14} \mathrm{CO}_{3}$ by algae and bacteria, a subsample (Vial 2, Fig. 1) was incubated in the dark.

As it was impossible to separate completely the algae from the bacteria by differential filtration, 4 further subsamples were treated as follows (Fig. 1): A subsample (Vial 3) was incubated with $0.25 \mu \mathrm{Ci}{ }^{14} \mathrm{C}$ glucose (specific activity $200-350 \mathrm{mCi} \mathrm{mmol}^{-1}$; Derenbach and Williams, 1974). Since bacteria take up the glucose, any radioactivity remaining on the 2 filters after filtration represents bacterial distribution.

I have assumed that bacterial uptake of exudates is equivalent to bacterial glucose uptake. Hence the amount of radioactivity on the $3 \mu \mathrm{m}$ filter of Vial 1 due to bacteria, can be calculated. This value was then substracted from the counts of the $3 \mu \mathrm{m}$ filter of Vial 1 and added to those obtained on the $0.2 \mu \mathrm{m}$ filter. A blank (Vial 4) was run to determine ${ }^{14} \mathrm{C}$-glucose absorption.

Another correction was made for small algae which may pass through the $3 \mu \mathrm{m}$ filter. Their radioactivity was measured together with the bacterial radioactivity on the $0.2 \mu \mathrm{m}$ filter. Therefore, a prefiltered subsample (Vial 6) was incubated with $\mathrm{NaH}^{14} \mathrm{CO}_{3}$. After incubation, aliquots were filtered only through a $0.2 \mu \mathrm{m}$ filter. The radioactivity on this filter was assumed to be due to small algae. Only this value was used to correct the radioactivity on the $0.2 \mu \mathrm{m}$ filter of Vial 1 . The 4 th subsample was incubated without any tracer. Aliquots were also filtered through $3 \mu \mathrm{m}$ and $0.2 \mu \mathrm{m}$ filters, which were later used for measurements of chlorophyll a.

The calculations are summarized in the following equations:

(1) Algal in-

$\begin{aligned} & \text { Algal in }- \\ & \text { corporation }\end{aligned}=\frac{\left(a_{1}-b_{1}+c-d\right) \times 1.05 \times \mathrm{mg} \mathrm{C} \mathrm{I}^{-1}}{e}$

$a_{1}=d p m$ on $3 \mu \mathrm{m} \mathrm{Vial} 1 ; b_{1}=$ dpm on $3 \mu \mathrm{m}$ Vial $2 ;$

$c=\mathrm{dpm}$ on $0.2 \mu \mathrm{m}$ Vial $6-\mathrm{dpm}$ on $0.2 \mu \mathrm{m}$ Vial 2 ;

$d=\frac{a^{\prime}}{b^{\prime}} \cdot c^{\prime}$

$a^{\prime}=d p m$ on $3 \mu \mathrm{m}$ Vial $3-d p m$ on $3 \mu \mathrm{m}$ Vial 4 ;

$b^{\prime}=\mathrm{dpm}$ on $0.2 \mu \mathrm{m}$ Vial $3-\mathrm{dpm}$ on $0.2 \mu \mathrm{m} \mathrm{Vial} \mathrm{4;}$

$c^{\prime}=\mathrm{dpm}$ on $0.2 \mu \mathrm{m}$ Vial $1-\mathrm{dpm}$ on $0.2 \mu \mathrm{m}$ Vial 6 .

$e=d p m$ added to the same volume which was

filtered. The factor 1.05 is the discrimination factor after Strickland and Parsons (1972).

(2) Bacterial incorporation of exudates

$=\frac{\left(a_{2}-b_{2}-c+d\right) \times 1.05 \times \mathrm{mg} \mathrm{C} \mathrm{l}^{-1}}{e}$

$a_{2} \hat{=} a_{1}$ for $0.2 \mu \mathrm{m}$ filter; $b_{2} \hat{=} b_{1}$ for $0.2 \mu \mathrm{m}$ filter.

(3) Dissolved exudates $=\frac{\left(a_{3}-b_{3}\right) \times f \times 1.05 \times \mathrm{mg} \mathrm{C} \mathrm{l}^{-1}}{e}$

$a_{3} \hat{=} a_{1}$ for filtrate; $b_{3} \hat{=} b_{1}$ for filtrate; $f=$ dilution factor (washing water).

The above equations are combined as follows to yield the required results:

$1+2+3=$ primary production during the given incubation time ( $\mathrm{mg} \mathrm{C}^{-1}$ )

$2+3=$ released organic matter $\left(\mathrm{mg} \mathrm{C}^{-1}\right)$

$\frac{2}{1+2+3}=\%$ bacterial uptake of primary products

$\frac{2}{2+3}=\%$ bacterial uptake of total exudates.

Total carbonate, nitrate, nitrite, and ammonium concentrations were determined after Grasshoff (1976), and phosphate after Murphy and Riley (1962). Chlorophyll a measurements were done fluorometrically (Lorenzen, 1966). 
Direct counts of bacteria were performed on black stained (sudan black) $0.2 \mu \mathrm{m}$ polycarbonate filters using the fluorescent dye acridine orange (Zimmermann and Meyer-Reil, 1974, Hobbie et al., 1977). To calculate bacterial biomass, the lengths of bacteria were measured and mean volumes used after Zimmermann (1977). Bacterial carbon was calculated assuming that $10 \%$ of the wet weight is due to organic carbon. Phytoplankton was counted in fixed samples (Lugol's solution; Vial 7, Fig. 1) using the technique of Utermöhl (1958). Cells were measured and carbon content calculated after Smetacek (1975).

\section{RESULTS}

Approximate isotopic equilibrium conditions between labelled ${ }^{14} \mathrm{C}$-organic substances and ${ }^{14} \mathrm{CO}_{3}$ were obtained within $6 \mathrm{~h}$ (Fig. 2). The slope of the curve of dissolved exudate release decreases during incubation. Dissolved exudates as percentage of pri-

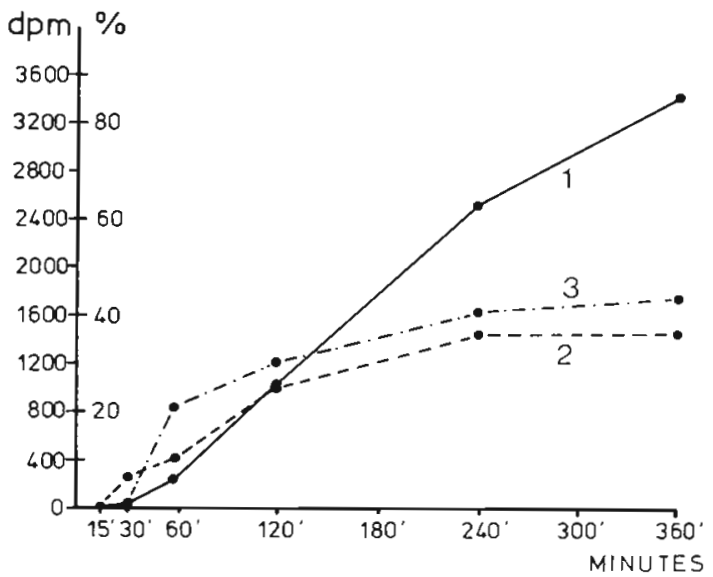

Fig. 2. Time-course experiments with natural water samples. 1 dissolved exudates; 2 activity on $0.2 \mu \mathrm{m}$ filters; 3 dissolved exudates as percentage of total primary production (dpm: disintegrations $\min ^{-1}$ )

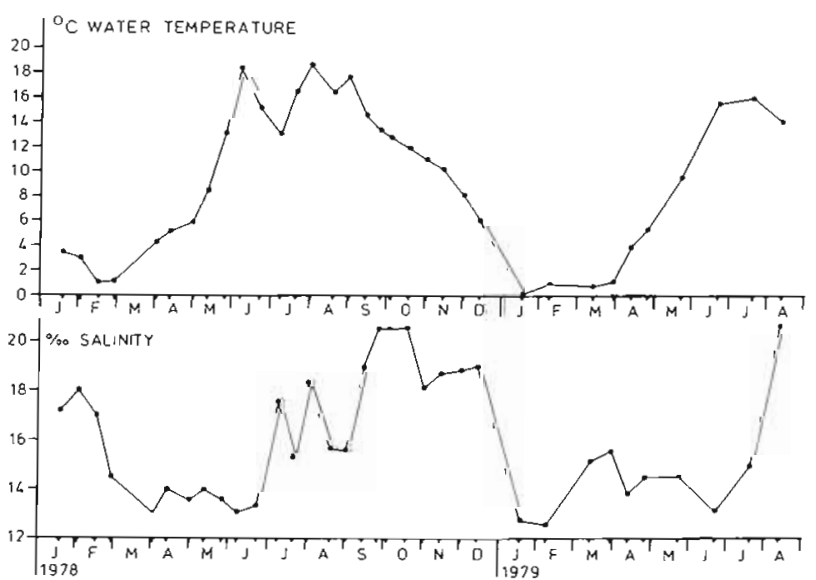

Fig. 3. Water temperature and salinity mary production, as well as bacterial incorporation of exudates, approach saturation.

Fig. 3 shows the yearly pattern of water temperature and salinity at the station during the period of investigation. Changes in salinity are influenced by water exchange (Lenz, 1977). The yearly pattern of inorganic nutrients (Figs. 4 and 5) is mainly caused by phytoplankton development. The trend is for nutrients to decrease in spring when phytoplankton starts to grow. The concentrations remain low during summer; regeneration occurs during winter (Rheinheimer, 1977, Szwerinski, 1981). Abnormally high peaks (March 1978, February and April 1979) for nitrate may have been caused by a small eutrophied fresh-water river which flows into the Kiel Fjord.

Fig. 6 illustrates the primary production of phytoplankton after 6 and $24 \mathrm{~h}$. The values after $6 \mathrm{~h}$ incuba-

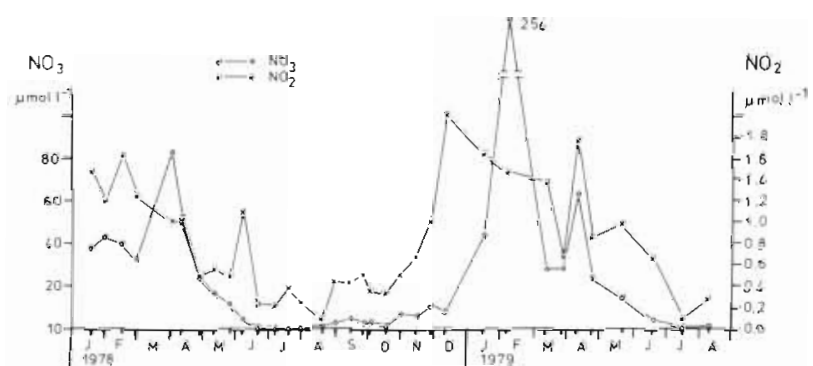

Fig. 4. Concentration of nitrate and nitrite

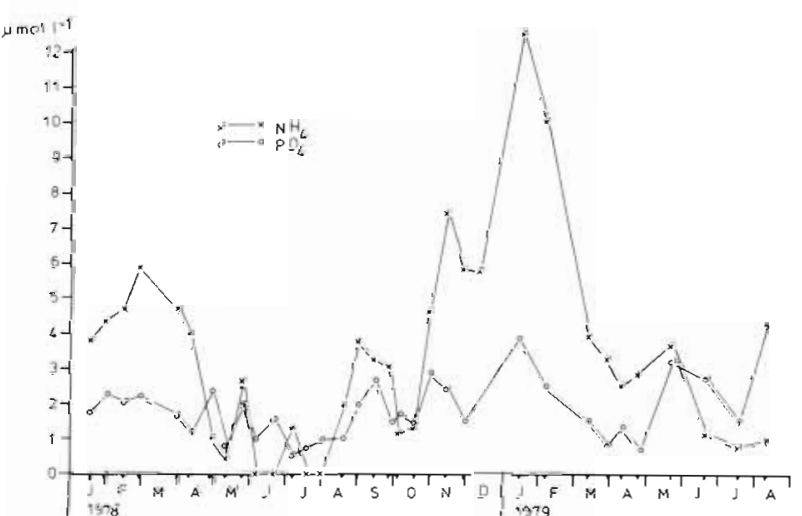

Fig. 5. Concentration of ammonium and phosphate

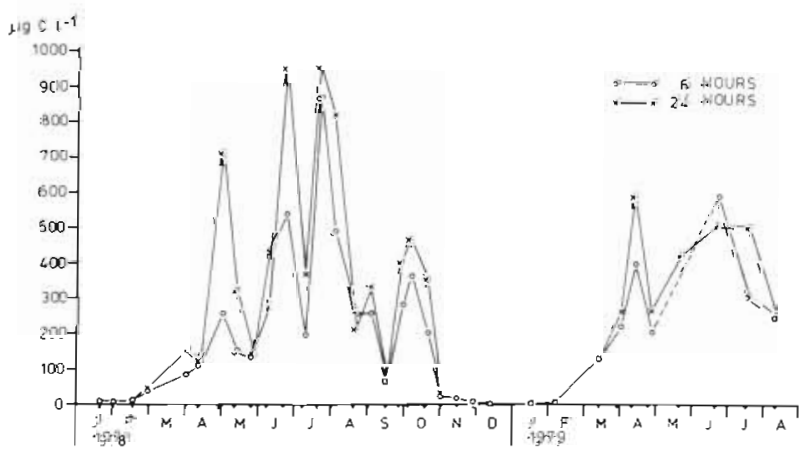

Fig. 6. Total primary production after 6 and $24 \mathrm{~h}$ incubation 
tion probably represent gross production, as it can be assumed that photorespiration and respiration are negligible during such short incubation; 24 h values represent the production on a daily basis. The $24 \mathrm{~h}$ values may also serve as indicators of the physiological condition of the algae: if production after $24 \mathrm{~h}$ is far below the production after $6 \mathrm{~h}$ it is possible that the algae have a quick catabolism and do not use the primary products for increasing their biomass.

The data in Fig. 6 comprise the particulate production on both $3 \mu \mathrm{m}$ and $0.2 \mu \mathrm{m}$ filters as well as the dissolved fraction. During the period of investigation several algal blooms were recorded, some of which had a high production. Fig. 7 shows the carbon content of different species responsible for the primary production. In spring 1978 and 1979 mainly diatoms were found, followed by mixed populations of nanoflagellates, dinoflagellates and diatoms in summer, and again diatoms in autumn.

Fig. 8a shows the total exudates released (dissolved exudates plus particulate bound on $0.2 \mu \mathrm{m}$ filters); the same data are expressed as percentage of the primary production in Fig. 8b. Release of exudates fluctuates

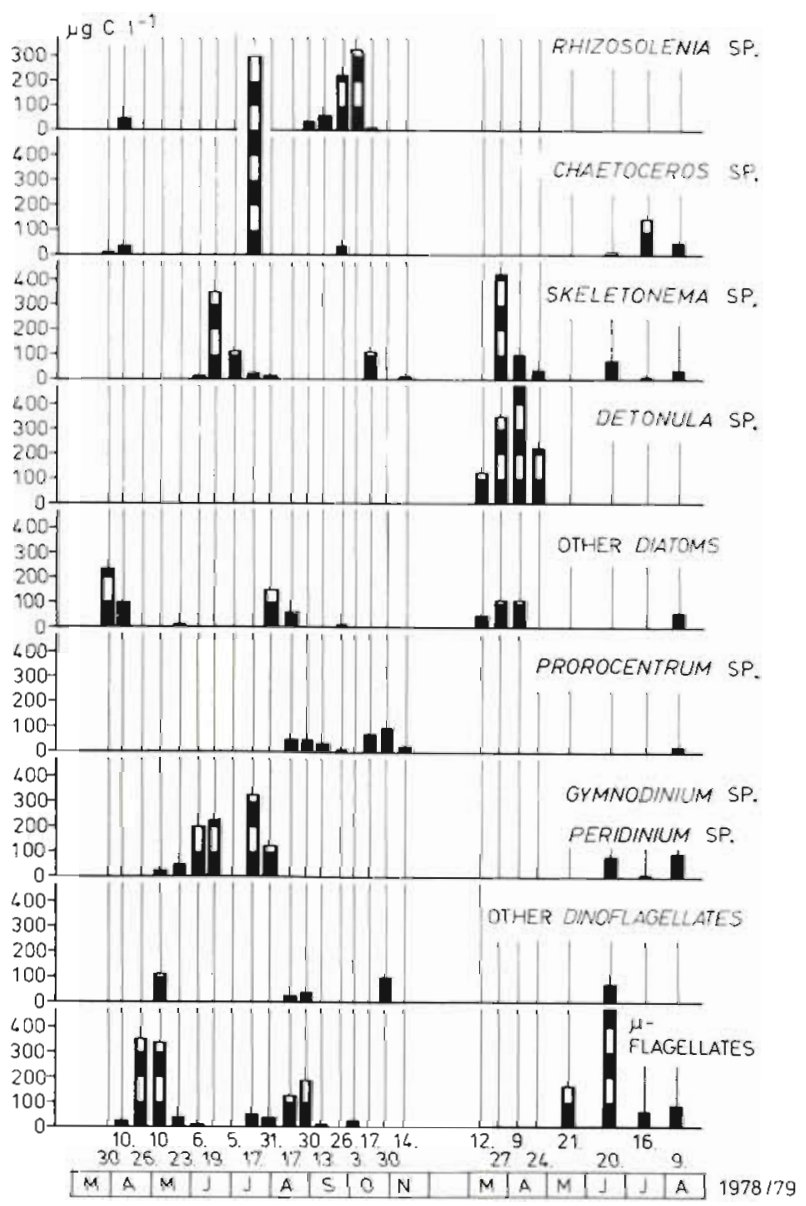

Fig. 7. Composition of algal populations expressed as carbon content for the different species in the water sample
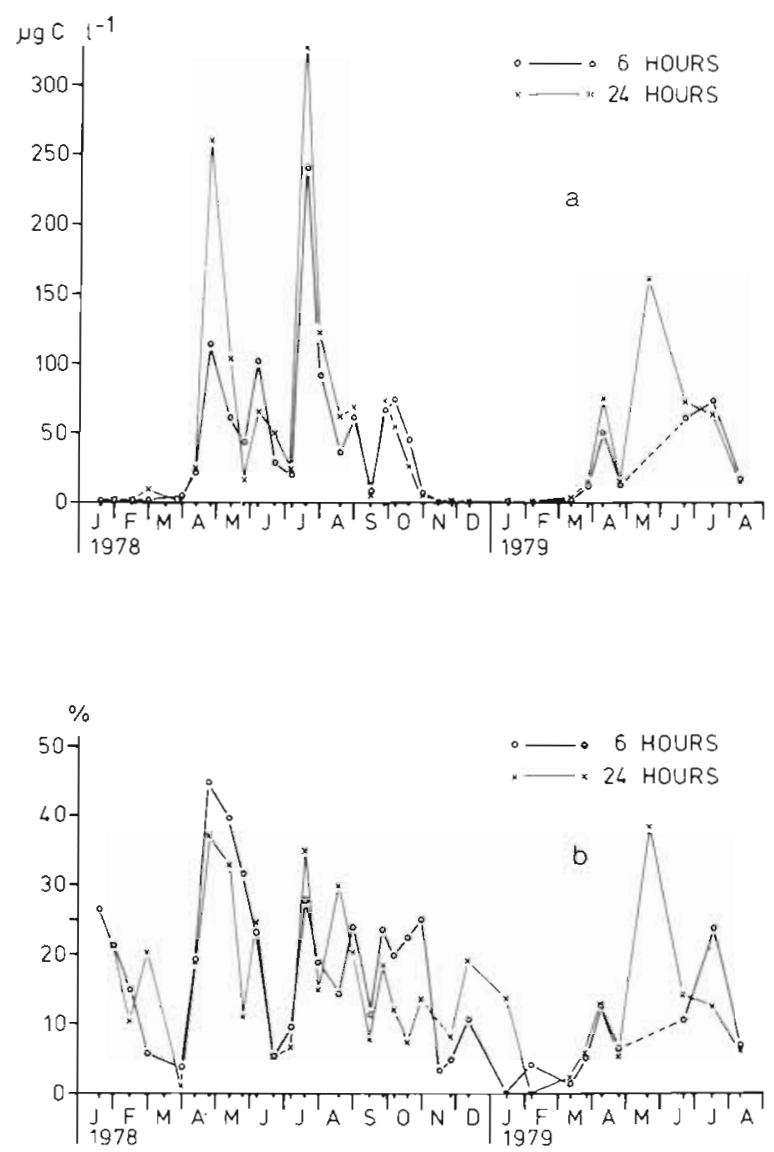

Fig. 8. Total exudates after 6 and $24 \mathrm{~h}$ incubation, expressed as $\mu \mathrm{C}^{-1}(\mathrm{a})$, and as percentage of total primary production (b)

during the year; the higher the primary production the higher the concentration of total exudates. There is little difference in percentage release of exudates between $6 \mathrm{~h}$ and $24 \mathrm{~h}$ incubation indicating that organic substances are released mainly during the light phase. The highest concentration of total exudates $\left(239 \mu \mathrm{g} \mathrm{C}^{-1}\right)$ was found in July 1978 after $6 \mathrm{~h}$ incubation. This corresponds to $27.6 \%$ of the total primary production. No correlation was found between primary production and percentage release of exudates.

A comparison between percentage release of exudates between the main algal species in the samples shows that some algal species release more organic substances than others. Skeletonema costatum was the major algal species on 19.6. and 5. 7.78, 27. 3 . $79,9.4 .79,24.4 .79,20.6 .79$ and 9. 8. 79. The percentage release of the primary products ranged from a minimum of 5.1 on the 19.6. 78 to a maximum of $12.5 \%$ on the 9. 4. 79. When mainly nanoflagellates were present in the sample (April and May 1978, June 1979 ) the release was between 10 and $40 \%$ of primary 
production. In late autumn 1978 it appears that the release of slightly over $20 \%$ of primary production after $6 \mathrm{~h}$, is due to Prorocentrum micans. Chaetoceros sp. which was present on 17.7 .78 released $27.6 \%$ of its primary production. Gymnodinium $s p$. and Peridinium sp. appear to release very small amounts.

Fig. 9a documents bacterial incorporation of exudates during $6 \mathrm{~h}$ and $24 \mathrm{~h}$ incubation. In spring, there is a time lag of bacterial activity when compared with primary production. The fraction of incorporated exudates is usually higher after $24 \mathrm{~h}$ incubation. In those instances where the production after $24 \mathrm{~h}$ was more than 4 times higher than the production after $6 \mathrm{~h}$, isotopic equilibrium had probably not been reached after $6 \mathrm{~h}$. In some cases bacterial incorporation of exudates was higher after $6 \mathrm{~h}$ than after $24 \mathrm{~h}$. This might be due to different uptake rates by bacteria during the day. It is also possible that the bacteria in these experiments use the organic substances mainly for their energy metabolism.
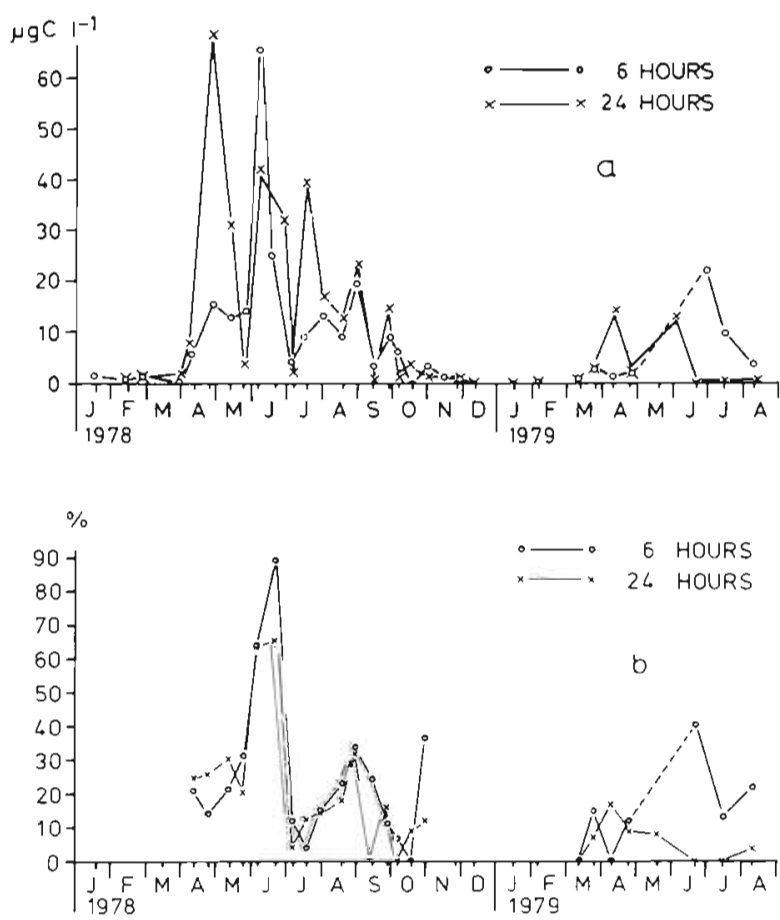

Fig. 9. Bacterial incorporation of exudates after 6 and $24 \mathrm{~h}$ incubation, expressed as $\mu \mathrm{g} \mathrm{C} 1^{-1}(\mathrm{a})$, and as percentage of total exudates (b)

Maximum bacterial activity occurred in June 78 and in June 79 after $6 \mathrm{~h}$. This was also found by Larsson and Hagstrom (1979). Although water temperature reaches a maximum in June, this does not fully explain the increase of bacterial activity since water temperature remains high during July and August while the bacterial activity shows strong variations.

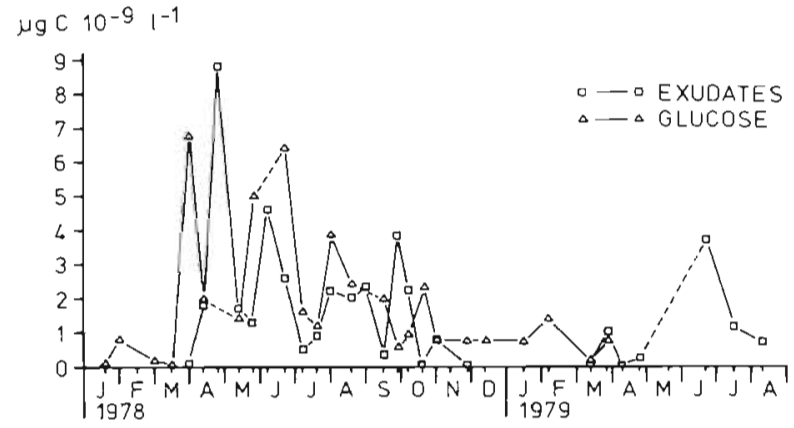

Fig. 10. Incorporation of exudates and glucose per bacterial cell after 6 h (glucose curve after Bölter, 1981)

To demonstrate a relationship between bacterial incorporation of exudates and abundance of algal species the bacterial uptake of exudates is shown as a percentage of total available exudates (Fig. 9b). Gymnodinium sp., Skeletonema costatum and nanoflagellates were present when the highest percentage of available exudates were incorporated by bacteria. This occurred in June 1978 when 90\%, and in June 1979 when $40 \%$ was taken up. Only $10 \%$ was incorporated when diatoms were present in the sample (i. e. 26. 9. 78 ). In one sample $(5.7 .78)$ in which only $S$. costatum occurred, bacteria incorporated $11.4 \%$ of the available exudates. In July 78 during a strong bloom of Chaetoceros sp. only $3.5 \%$ of the exudates was incorporated; a higher percentage was incorporated in autumn when Prorocentrum micans was present.

Fig. 10 illustrates the incorporation of exudates and glucose per bacterial cell. During summer there is a correlation between glucose and exudate incorporation, whereas in autumn and winter the reverse was observed.

\section{DISCUSSION}

The results show that the release of organic substances by natural phytoplankton populations and their immediate incorporation by bacteria can be measured by using careful differential filtration. Because of certain correction factors used, it is difficult to compare the results with those obtained elsewhere. It was found that the method applied played an important role in these investigations. Preliminary experiments (Wolter, 1980) have shown that there is up to $20 \%$ variation in exudation of primary products depending on whether filtration was carried out under vacuum or not. It was also found that small algae may pass through the $3 \mu \mathrm{m}$ filter and that they may contribute up to $35 \%$ of the total production.

Larsson and Hagstrom (1981) found that up to $70 \%$ of the activity on the $0.2 \mu \mathrm{m}$ filter was due to autotrophic productivity. For this reason it is obvious that a 
correction must be made for these small algae. Although the correction factor for bacteria associated with the algae on the $3 \mu \mathrm{m}$ filter was used in the calculations of the results, the value was found to be almost insignificant since only an average of $6 \%$ of the bacteria remained on the $3 \mu \mathrm{m}$ filter.

The time-course experiment revealed that an approximate isotopic equilibrium was reached within an incubation time of $6 \mathrm{~h}$; however, this may vary in different water samples. Saunders (1972) and Lancelot (1979) found that there may be a variation in the time for labelled organic substances to appear in the dissolved fraction. This depends on the metabolic pathways responsible for the production of substances released. Release of labelled organic matter, however, may be very rapid after addition of $\mathrm{NaH}^{14} \mathrm{CO}_{3}$ to the sample (Fogg, 1966; Lancelot, 1976; Nalewajko et al., 1976; Nalewajko and Schindler, 1976). Mague et al. (1980) found a rapid equilibrium between the compounds released and the new primary products. The results from the $24 \mathrm{~h}$ parallel incubation, done to obtain data on a daily basis and to signify the physiological condition of the algal population, revealed that in most cases $6 \mathrm{~h}$ were sufficient for attaining isotopic equilibrium. This was also found by Wiebe and Smith (1977), Lancelot (1979) and Larsson and Hagström (1979).

The $24 \mathrm{~h}$ incubation also showed that a higher percentage of exudates is released during the light phase of the incubation. The results of primary production, exudate release and bacterial incorporation of exudates are presented for the whole incubation time. To obtain an estimate of the hourly rate of exudate release, the linear slope of the dissolved exudates in Fig. 2 was used. The rate of exudate release was $7.4 \mu \mathrm{g}$ $\mathrm{Cl}^{-1} \mathrm{~h}^{-1}$

The rates calculated by Lancelot (1979) ranged from 0 to $16 \mu \mathrm{g} \mathrm{Cl}^{-1} \mathrm{~h}^{-1}$, and Larsson and Hagström (1979) found a release of $3 \mu \mathrm{g} \mathrm{C} 1^{-1} \mathrm{~h}^{-1}$. Using the calculation of Larsson and Hagström (1979) bacterial respiration was estimated from the hourly rate of exudate release (assuming that this rate is constant for the first $6 \mathrm{~h}$ ) and from the difference between dissolved exudates found after $6 \mathrm{~h}$ and the theoretical pool of released substances. The difference between available exudate and the measured incorporation of exudates by bacteria was probably due to respiration during incubation. This difference was calculated to be $29 \%$. Respiration of glucose by bacteria of the Kiel Fjord varied between 5 and $45 \%$ (Bölter, 1981). Herbst (1976) found that between 67 and $74 \%$ of Oscillatoria redekei exudate was respired.

During spring and summer 1978 incorporation plus respiration of glucose in the Kiel Fjord ranged from 0.8 to $15.3 \mu \mathrm{g} \mathrm{C} \mathrm{l} ~^{-1} \mathrm{~h}^{-1}$ (Bölter, 1981). It appears therefore, that bacteria utilize the main portion of exudates released. The similarity between the curves of bacterial uptake of exudates and exudate release is caused by the response of the bacterial population to the substances released. Bacterial activity begins to increase shortly after the first phytoplankton bloom even if the water temperature is low. In autumn bacterial activity decreases with a decrease in algal activity, while the water temperature remains relatively high. Similiar observations were made by Sieburth (1967) and Saltzmann (1980). Significant positive rank correlations could be found between bacterial incorporation of exudates and glucose (Bölter, 1981). The natural glucose concentrations (Liebezeit, 1980) only show a positive correlation with bacterial exudate incorporation and primary production during spring, summer and autumn - not in winter. These results indicate that phytoplankton seems to play a major role in nutrient supply for bacteria, and that it releases substances which are taken up similarly to glucose.

Several authors (Guillard and Wangersky, 1958; Guillard and Hellebust, 1971; Stabel, 1976; Bolze and Soeder, 1978, Jüttner and Matuschek, 1978) have reported that glucose was a constituent of algal exudates. Moshiri et al. (1979) also found a positive relationship between dissolved glucose and primary production in surface water of an estuary in Florida.

On a $24 \mathrm{~h}$ basis the bacteria incorporated 0-65\% (mean value $20.9 \%$ ) of the total exudates for biomass production. This corresponds to $0-15.6 \%$ (mean value $3.6 \%$ ) of total primary production. Larsson and Hagström (1979) found that the bacterial production was $27 \%$ of total primary production. Their calculations are based on a $4 \mathrm{~h}$ incubation and are related to the total water column.

Although water temperature is fairly constant during summer, considerable variations in bacterial activity were found. This can be explained by the composition of the algal flora. The amount of exudate release varies with the algal composition in the Kiel Fjord. Fogg et al. (1965) and Steinberg (1978) could not find such a relationship, whereas Lee and Nalewajko (1978) reported that phytoflagellates and Scenedesmus released more primary products than other species. According to Hellebust (1965), cultures of Chaetoceros pelagicus and $C$. simplex released $20 \%$ of their primary products, whereas Exuviella sp. released only $3 \%$. My investigations have shown that Chaetoceros sp. released relatively high amounts $(\approx 27.6 \%)$, dinoflagellates - except Prorocentrum micans - low concentrations and Skeletonema costatum between $5.1 \%$ and $12.5 \%$. No definite relationship could be found with this method between the physiological condition of the algae and the percentage release of exudates. Bacteria incorporated between 0 and $65.6 \mu \mathrm{g} \mathrm{C}^{-1} \mathrm{~d}^{-1}$. The values of the bacterial standing stock during the 
investigation were of the same order of magnitude (Palmgren, 1981). They varied between 10 and $69.2 \mu \mathrm{g}$ $\mathrm{C}^{-1}$ with 2 exceptions of 92.9 and $112.05 \mu \mathrm{g} \mathrm{Cl}^{-1}$.

The data presented here confirm conclusions of other authors (e. g. Bauld and Brock, 1974; Derenbach and Williams, 1974; Gocke, 1977; Rheinheimer, 1977; Hoppe, 1978; Larsson and Hagström, 1979) that a considerable portion of dissolved organic substances flows directly from phytoplankton to bacteria. The importance of bacteria is therefore not only to be seen in their remineralization of organic substances but also in their transformation of dissolved organic material to a particulate form which is then available for bacterial feeders.

Acknowledgements. This study is part of the author's dissertation. I wish to thank Professor Dr. G. Rheinheimer for advice and comments on the manuscript. I also thank Mr. G. Dieckmann for critically reading the manuscript.

\section{LITERATURE CITED}

Bauld, J., Brock, T. D. (1974). Algal excretion and bacterial assimilation in hot spring algal mats. J. Phycol. 10: 101-106

Bölter, M. (1981). DOC-turnover and microbial biomass production. In: Proceedings of 15th European Marine Biological Symposium. Kieler Meeresforsch. 5 (Sonderh.): 304-310

Bolze, A., Soeder, C. J. (1978). Konzentrationsänderungen der extrazellulären Substanz bei Synchronkulturen von Scenedesmus quadricauda vor. alternans HORTOB. Arch. Hydrobiol. 82: 142-154

Derenbach, J. B., Williams, P. J. LeB. (1974). Autotrophic and bacterial production: fractionation of plankton populations by differential filtration of samples from the English Channel. Mar. Biol. 25: 263-269

Fogg, G. E. (1966). The extracellular products of algae. Oceanogr. Mar. Biol. A. Rev. 4: 195-212

Fogg, G. E., Nalewajko, C., Watt, W D. (1965). Extracellular products of phytoplankton photosynthesis. Proc. R. Soc. (Ser. B) 162: 517-534

Gocke, K. (1977). Heterotrophic activity. In: Rheinheimer, G (ed.) Microbial ecology of a brackish water environment. Springer Verlag, Berlin, Heidelberg, New York, pp 198-221

Grasshoff, K. (1976). Methods of seawater analysis, Verlag Chemie Weinheim, New York

Guillard, R. R. L., Hellebust, J. A. (1971). Growth and the production of extracellular substances by two strains of Phaeocystis poucheti. J. Phycol. 7: 330-338

Guillard, R. R. L., Wangersky, P. J. (1958). The production of extracellular carbohydrates by some marine flagellates. Limnol. Oceanogr. 3: 449-545

Hellebust, J. A. (1965). Excretion of some organic compounds by marine phytoplankton. Limnol. Oceanogr. 10: 192-206

Herbst, V (1976). Physiologische Untersuchungen zur Kopplung des Stoffwechsels von Oscillatoria redekei van Goor und Begleitbakterien. Dissertation Universität Kiel

Hobbie, J. E., Daley, R. J., Jasper, S. (1977). Use of Nuclepore filters for counting bacteria by fluorescence microscopy. Arch. Microbiol. 33: 1225-1228
Hoppe, H.-G. (1978). Relations between active bacteria and heterotrophic potential in the sea. Netherlands J. Sea. Res. 12: 78-98

Jütner, F., Matuschek, T. (1978). The release of low molecular weight compounds by the phytoplankton in an eutrophic lake. Wat. Res. 12: 251-255

Lancelot, C. (1979). Gross excretion rates of natural marine phytoplankton and heterotrophic uptake of excreted products in the Southern North Sea, as determined by shortterm-kinetics. Mar. Ecol. Prog. Ser. 1: 179-186

Larsson, U., Hagström, A. (1981). Fractionated phytoplankton, primary production, exudate release and bacterial production in a baltic eutrophication gradient. MS submitted to Mar. Biol.

Larsson, U., Hagström, A. (1979). Phytoplankton exudate release as an energy source for the growth of pelagic bacteria. Mar. Biol. 52: 199-206

Lee, K., Nalewajko, C. (1978). Photosynthesis extracellular release and glycollic acid uptake by plankton: fractionation Studies. Verh. int. Verein. theor. angew. Limnol. 20: $257-262$

Lenz, J. (1977). Hydrographic conditions. In: Rheinheimer, G. (ed.) Microbial ecology of a brackish water environment. Ecological Studies 25. Springer Verlag, Berlin, Heidelberg, New York, pp. 12-25

Liebezeit, G. (1980). Aminosäuren und Zucker im marinen Milieu - Neuere analytische Methoden und ihre Anwendung. Dissertation Universität Kiel

Lorenzen, G. J. (1966). A method for the continuous measurement of in vivo chlorophyll concentration. Deep Sea Res. 13: 223-227

Mague, T. H., Friberg, E., Hughes, D. J., Morris, I. (1980). Extracellular release of carbon by marine phytoplankton: a physiological approach. Limnol. Oceanogr. 25: 262-279

Moshiri, G. A., Crumpton, W. G., Aumen, N. G. (1979). Dissolved glucose in a Bayon Estuary, possible sources and utilization by bacteria. Hydrobiologia 62: 71-74

Murphy, J., Riley, J. P. (1962). A modified single solution method for the determination of phosphate in natural waters. Anal. Chim. Acta 27: 31-36

Nalewajko, C. (1966). Photosynthesis and excretion in various planktonic algae. Limnol. Oceanogr. 1: 1-10

Nalewajko, C., Dunstall, G., Shear, H. (1976). Kinetics of extracellular release in axenic algae and in mixed algalbacterial cultures: significance in estimation of total (gross) phytoplankton excretion rates. J. Phycol. 12: 1-5

Nalewajko, C., Schindler, D. W. (1976). Primary production, extracellular release and heterotrophy in two lakes in the ELA, Northwestern Ontario. J. Fish. Res. Bd Can. 23: 219-226

Palmgren, U. (1981). Untersuchungen über die Abhängigkeit der Bakterienpopulation von abiotischen und biotischen Parametern in einem Brackwassergebiet. Dissertation Universität Kiel

Rheinheimer, G. (ed.) (1977). Microbial ecology of a brackish water environment, Ecological Studies, Springer Verlag, Berlin, Heidelberg, New York

Saltzmann, H. A. (1980). Untersuchungen über die Veränderungen der Mikroflora beim Durchgang von Brackwasser durch die Kühlanlagen von Kraftwerken. Dissertation Universität Kiel

Saunders, G. W., Jr (1972). The kinetics of extracellular release of soluble organic matter by plankton. Verh. int. Verein. theor, angew. Limnol. 18: 140-146

Sharp, J. H. (1977). Excretion of organic matter. Do healthy cells do it? Limnol. Oceanogr. 22: 381-399

Sieburth, J. McN. (1967). Seasonal selection of estuarine 
bacteria by water temperature. J. exp. mar. Biol. Ecol. 1: 98-121

Smetacek, V. (1975). Die Sukzession des Phytoplanktons in der westlichen Kieler Bucht. Dissertation Universität Kiel

Smith, W. O., Jr., Barber, R. T., Huntsman, S. A. (1977). Primary production off the coast of Northwest Africa: excretion of dissolved organic matter and its heterotrophic uptake. Deep Sea Res. 24 : 35-47

Stabel, H. H. (1976). Gebundene Kohlenhydrate als stabile Komponenten im Schlöhsee und in Scenedesmus-Kulturen. Dissertation Universität Kiel

Steinberg, C. (1978). Freisetzung gelösten organischen Kohlenstoffs (DOC) verschiedener Molekülgrößen in Planktongesellschaften. Arch. Hydrobiol. 82: 155-165

Storch, T. A., Saunders, G. W. (1978). Phytoplankton extracellular release and its relation to the seasonal cycle of dissolved organic carbon in an eutrophic lake. Limnol. Oceanogr. 23: 112-119

Strickland, J. D. H., Parsons, T. R. (1972). A practical handbook of seawater analysis. Fisheries Research Board of Canada, Ottawa

Szwerinski, H. (1981). Nitrate formation by autotrophic nitrifying bacteria in coastal waters and sediments of the Kiel Bight. In: Proceedings of 15th European Marine
Biological Symposium. Kieler Meeresforsch. 5 (Sonderh.): 396-407

Utermöhl, H. (1958). Zur Vervollkommnung der quantitativen Phytoplankton-Methodik. Mitt. int. Verh. Limnol. 9: 1-38

Wiebe, W. J., Smith, D. F. (1977). Direct measurements of dissolved organic carbon release by phytoplankton and incorporation by microheterotrophs. Mar. Biol. 42: 213-223

Williams, P. J. LeB, Yentsch, C. S. (1976). An examination of photosynthetic production, excretion of dissolved organic compounds with reference to results from a coastal subtropical sea. Mar. Biol. 35: 31-40

Wolter, K. (1980). Untersuchungen zur Exsudation organischer Substanz und deren Aufnahme durch natürliche Bakterienpopulationen. Dissertation Universität Kiel

Zimmermann, R. (1977). Estimation of bacterial number and biomass by epifluorescence microscopy and scanning electron microscopy. In: Rheinheimer, G. (ed.) Microbial ecology of a brackish water environment. Ecological Studies 25: 103-118

Zimmermann, R., Meyer-Reil, L.-A. (1974). A new method for fluorescence staining of bacterial populations on membrane filters. Kieler Meeresforsch. 30: 24-27

This paper was presented by Professor G. Rheinheimer; it was accepted for printing on November 15, 1981 